\title{
Altered islet Beta-cell function before the onset of Type 1 (insulin-dependent) diabetes mellitus
}

\author{
S.S.S. Lo, M. Hawa, S. F. Beer, D. A. Pyke and R.D. G. Leslie \\ Diabetes Research Unit, Departments of Medicine and Therapeutics, Westminster Hospital, London, UK
}

Summary. To define the glucose to insulin dose-response relationship before the onset of diabetes, we studied 22 nondiabetic co-twins of patients with Type 1 (insulin-dependent) diabetes mellitus and nine control subjects. All had intravenous glucose tests at $0.02,0.1$ and $0.5 \mathrm{~g} / \mathrm{kg}$ and were followedup prospectively for at least 6 years. Seven twins developed diabetes a mean of 7 months later; the remaining 15 are now unlikely to develop diabetes. The seven pre-diabetic twins had higher fasting insulin levels than control subjects $(4.2 \pm 2.0$ vs $1.8 \pm 1.8 \mathrm{nmol} / \mathrm{l} ; p<0.05)$; but lower glucose clearance $(1.0 \pm 0.5$ vs $1.9 \pm 0.7 \% / \mathrm{min} ; p<0.05)$, first phase insulin response at $0.5 \mathrm{~g} / \mathrm{kg}(21.1 \pm 23.2$ vs $143 \pm 50 \mathrm{nmol} / 1$; $p<0.0001)$, and total insulin responses at $0.1 \mathrm{~g} / \mathrm{kg}(p<0.05)$ and $0.5 \mathrm{~g} / \mathrm{kg}(p<0.00005)$. Using a curve-fitting programme, the normal glucose to insulin relationship was lost in prediabetic twins who had lower coefficient of determination $\left(\mathrm{R}^{2}\right)$ than control subjects $(p<0.01)$. In contrast, 15 low-risk twins and their nine control subjects had similar fasting glucose and insulin levels, glucose clearance, $\mathrm{R}^{2}$ and insulin secretory responses to different glucose loads. The positive predictive values of subnormal $\mathrm{R}^{2}$ and subnormal first phase insulin response were $67 \%$ and $58 \%$ respectively. These observations demonstrate an altered glucose to insulin dose-response relationship and loss of maximum insulin secretory response to glucose before the onset of Type 1 diabetes.

Key words: Identical twins, Type 1 (insulin-dependent) diabetes mellitus, intravenous glucose, insulin response.
Type 1 (insulin-dependent) diabetes mellitus is due to destruction of the Beta-cells of the islets of Langerhans. The disease is thought to be caused by environmental factors operating in a genetically susceptible host to initiate a destructive immune process [1]. At the time of diagnosis about $80 \%$ of the islets contain no Beta-cells and the islets are heavily infiltrated with lymphocytes [2]. The disease process is slow; some of the immune and metabolic changes can occur many months, even years, before the onset of clinical diabetes [3]. During this pre-diabetic period the insulin response to i.v. glucose may be decreased [3]. This decreased insulin response could be due either to decreased sensitivity to glucose or decreased islet Betacell secretory capacity. To define the relationship between glucose and insulin before the onset of diabetes we studied a group of non-diabetic identical co-twins of patients with Type 1 diabetes who were at risk of also developing the disease and then followed them up prospectively.

\section{Subjects and methods}

\section{Patients}

It is our policy to see non-diabetic twins at least annually when they are within 6 years of the diagnosis of diabetes in their index twin and every 2 to 3 years thereafter. For this study we tested, on a single oc- casion, a consecutive series of 22 non-diabetic identical co-twins of Type 1 diabetic patients who were seen between January 1985 and December 1986. All the twins had oral glucose tolerance tests (glucose was given as $75 \mathrm{~g}$ or $1.75 \mathrm{~g} / \mathrm{kg}$ whichever was the less) to confirm that they were not diabetic [4]. Monozygosity was established in all the twin pairs as previously described [5]. Nine control subjects (Table 1) were also tested over the same period as the twins. These control subjects were selected to achieve a similar distribution for age and body mass index (BMI) to the twins and had no family history of diabetes, were taking no drugs, had no clinical signs or symptoms of illness and were eating their normal diet at the time of testing. The subjects or their parents gave informed consent and the study was approved by the ethical committees at Westminster Hospital and King's College Hospital.

All 22 non-diabetic twins were followed prospectively until 1 January 1991. During the follow-up period, seven twins developed diabetes ( $7 \pm 2$ months after testing) and are referred to as prediabetic twins. The remaining 15 twins have been followed for a minimum of 6 years $(13.4 \pm 7.0$ years) from the diagnosis of Type 1 diabetes in their co-twins and have not developed diabetes. The risk for these twins now developing Type 1 diabetes is less than $2 \%$ [6].

At the end of the study period, we therefore had two groups: seven pre-diabetic twins and 15 low risk non-diabetic twins. The seven pre-diabetic twins were compared with seven of the nine control subjects of similar age (16.9 \pm 5.8 vs $18.5 \pm 6.3$ years) and BMI $\left(19.8 \pm 2.5 \mathrm{vs} 20.6 \pm 1.5 \mathrm{~kg} / \mathrm{m}^{2}\right)$. The 15 low risk twins were compared with all nine control subjects of similar age $(22.4 \pm 5.3$ vs $21.1 \pm 7.6$ years $)$ and BMI (22.5 \pm 5.3 vs $\left.21.1 \pm 1.9 \mathrm{~kg} / \mathrm{m}^{2}\right)$. 
Table 1. Clinical information of subjects at the time of the study

\begin{tabular}{|c|c|c|c|c|c|}
\hline & Age & Sex & BMI & ICA & $\begin{array}{l}\text { JDF } \\
\text { units }\end{array}$ \\
\hline \multicolumn{6}{|c|}{ Control subjects } \\
\hline 1 & 13.7 & $\mathrm{~F}$ & 19.5 & - & $<10$ \\
\hline 2 & 28.5 & $\mathrm{~F}$ & 23.0 & - & $<10$ \\
\hline 3 & 14.0 & $\mathrm{~F}$ & 18.2 & - & $<10$ \\
\hline 4 & 24.5 & $\mathrm{~F}$ & 21.9 & - & $<10$ \\
\hline 5 & 30.4 & $\mathrm{~F}$ & 22.0 & - & $<10$ \\
\hline 6 & 13.2 & M & 20.4 & - & $<10$ \\
\hline 7 & 21.7 & M & 20.7 & - & $<10$ \\
\hline 8 & 30.5 & M & 24.6 & - & $<10$ \\
\hline 9 & 14.0 & M & 20.6 & - & $<10$ \\
\hline \multicolumn{6}{|c|}{ Pre-diabetic twins } \\
\hline 1 & 23.0 & $\mathrm{~F}$ & 22.3 & + & 80 \\
\hline 2 & 27.0 & $\mathrm{~F}$ & 21.0 & + & 40 \\
\hline 3 & 16.7 & $\mathrm{~F}$ & 23.5 & + & 160 \\
\hline 4 & 11.8 & $F$ & 19.1 & + & 40 \\
\hline 5 & 13.9 & M & 16.9 & + & 320 \\
\hline 6 & 12.0 & M & 18.6 & + & 160 \\
\hline 7 & 13.9 & M & 17.3 & + & 80 \\
\hline \multicolumn{6}{|c|}{ Low risk twins } \\
\hline 8 & 16.2 & $\mathrm{~F}$ & 19.6 & - & $<10$ \\
\hline 9 & 25.0 & $\mathrm{~F}$ & 20.4 & - & $<10$ \\
\hline 10 & 31.8 & $\mathrm{~F}$ & 18.7 & - & $<10$ \\
\hline 11 & 22.7 & $\mathrm{~F}$ & 27.7 & - & $<10$ \\
\hline 12 & 30.5 & $\mathrm{~F}$ & 23.8 & - & $<10$ \\
\hline 13 & 20.2 & $\mathrm{~F}$ & 21.5 & - & $<10$ \\
\hline 14 & 29.1 & $\mathrm{~F}$ & 26.3 & - & $<10$ \\
\hline 15 & 27.1 & M & 26.9 & - & $<10$ \\
\hline 16 & 21.5 & $\mathrm{M}$ & 24.0 & - & $<10$ \\
\hline 17 & 21.0 & M & 24.5 & - & $<10$ \\
\hline 18 & 19.9 & M & 22.3 & - & $<10$ \\
\hline 19 & 18.3 & M & 23.8 & - & $<10$ \\
\hline 20 & 19.4 & M & 19.0 & - & $<10$ \\
\hline 21 & 12.8 & M & 16.3 & - & $<10$ \\
\hline 22 & 21.2 & M & 22.1 & - & $<10$ \\
\hline
\end{tabular}

ICA, islet cell antibodies; BMI, body mass index; JDF units, Juvenile Diabetes Foundation units

\section{Methods}

Each subject was given i.v. glucose on a single occasion using $20 \%$ dextrose at $0.5 \mathrm{~g} / \mathrm{kg}, 0.1 \mathrm{~g} / \mathrm{kg}$ and $0.02 \mathrm{~g} / \mathrm{kg}$ body weight. The doses and time intervals between each dose were selected to define the dose-response relationship between glucose and insulin as previously reported by Porte et al. [7]. Following an overnight fast, the subjects were studied in the supine position at least 15 min after a venous cannula was inserted into the antecubital vein under local anaesthesia. Fasting blood samples were taken at -10 and 0 min after which glucose $(0.5 \mathrm{~g} / \mathrm{kg}$ dissolved in a $20 \%$ dextrose solution $)$ was injected i.v. over a period of $2 \mathrm{~min}$. Venous blood was sampled at 3,5 , $7.5,10,15,20,25$ and $30 \mathrm{~min}$, timed from the beginning of the glucose injection. After a rest period a blood sample was taken at $120 \mathrm{~min}$ followed by a second glucose injection $(0.1 \mathrm{~g} / \mathrm{kg})$ administered over $1 \mathrm{~min}$. Further blood samples were obtained at 123, 125, 127.5, 130, $135,140,145$ and $150 \mathrm{~min}$. After another rest period a blood sample was taken at $180 \mathrm{~min}$ followed by a third injection of glucose $(0.02 \mathrm{~g} / \mathrm{kg})$ given over $15 \mathrm{~s}$. Blood samples were taken at 183,185 , $187.5,190,195,200,205$ and $210 \mathrm{~min}$. All blood samples were obtained for the measurement of whole blood glucose and serum insulin.

Whole blood glucose was measured by a glucose oxidase method (Yellow Springs Analyser, Yellow Springs, Ohio, USA). Serum insulin levels were measured by a modification of the double antibody radioimmunoassay method using monoiodinated tyrosine A14 labelled insulin [8]. Blood glucose was measured immediately, while samples for insulin were batched and measured at the same time. The mean within batch coefficient of variation for our insulin assay was $4 \%$.

\section{Islet cell antibody determination}

Undiluted sera from twins were screened for islet cell antibodies (ICA). ICA was established by testing serum with indirect immunofluorescence on a fresh group 0 cryofixed human pancreas [9]. The titre of each sample was determined by serial doubling dilution. The same pancreas, reagents and incubation conditions gave end-point titres of 32 with the putative ICA standard equivalent to 80 Juvenile Diabetes Foundation units (JDF). The results are presented as positive or negative with positive tests being greater than $10 \mathrm{JDF}$ units.

\section{Calculations}

1) Fasting whole blood glucose and serum insulin levels were calculated as the mean of the -10 and 0 min values.

2) Intravenous glucose clearance rates $\left(\mathrm{K}_{\mathrm{g}}\right)$ were calculated by a method of least squares, using the natural log of the glucose concentration from 15 to $30 \mathrm{~min}$ after $0.5 \mathrm{~g} / \mathrm{kg}$ glucose load and expressed as a $\%$ per min.

3) Total insulin responses were calculated as the areas under the curve and above the basal values from time $0-30 \mathrm{~min}, 120-150 \mathrm{~min}$ and 180-210 min respectively following each glucose injection.

4) The first phase insulin response (FPIR) following the first glucose load $(0.5 \mathrm{~g} / \mathrm{kg})$ was calculated as the area under the $0-10 \mathrm{~min}$ curve and above the fasting level.

5) The second phase response was estimated as the total insulin response minus the FPIR.

6) The glucose to insulin dose-response relationship was assessed by calculating the mean glucose and insulin levels during fasting and in the 3-10 min after each of the three glucose injections. We did not use areas under the insulin response following glucose injection, as fasting insulin levels were used as a point on the dose-response curve. These four mean glucose and insulin levels for each subject were examined by a computer curve fitting programme (Apple Cricket graph; logarithmic curve fitting). This programme uses a logarithmic regression equation such that $\mathrm{Y}=\mathrm{C} \log \mathrm{X}+\mathrm{E}$ where $\mathrm{Y}$ is the insulin level and $X$ is the glucose level and $C$ and $E$ are constants. It has been established previously that insulin responses to glucose in normal subjects reach a maximum at i.v. glucose loads less than $0.5 \mathrm{~g} / \mathrm{kg}$ body weight [7]. The glucose loads we used and the time intervals between each load were selected to establish the glucose to insulin dose-response relationship.

7) For each subject, the curve fitting precision was estimated by $R^{2}$, the coefficient of determination. We anticipate that normal subjects would maintain a perfect logarithmic dose-response relationship between glucose and insulin such that $\mathrm{R}^{2}$ would approximate to 1.0. Thus, loss of the glucose to insulin dose-response relationship would result in a poor curve fit and a decreased coefficient of determination.

\section{Predictive value}

To assess low $\mathrm{K}_{\mathrm{g}}$, FPIR and $\mathrm{R}^{2}$ as predictors of Type 1 diabetes, it is necessary to know the chances of twins developing the disease. We can be certain in this study that twins are pre-diabetic as they were followed-up until the onset of Type 1 diabetes and that the low risk twins who remain non-diabetic now have less than a $2 \%$ risk of developing diabetes [6]. We estimated: a) the positive predictive value, by calculating the number of twins in whom the levels were below the normal range and who later developed Type 1 diabetes as a percent- 


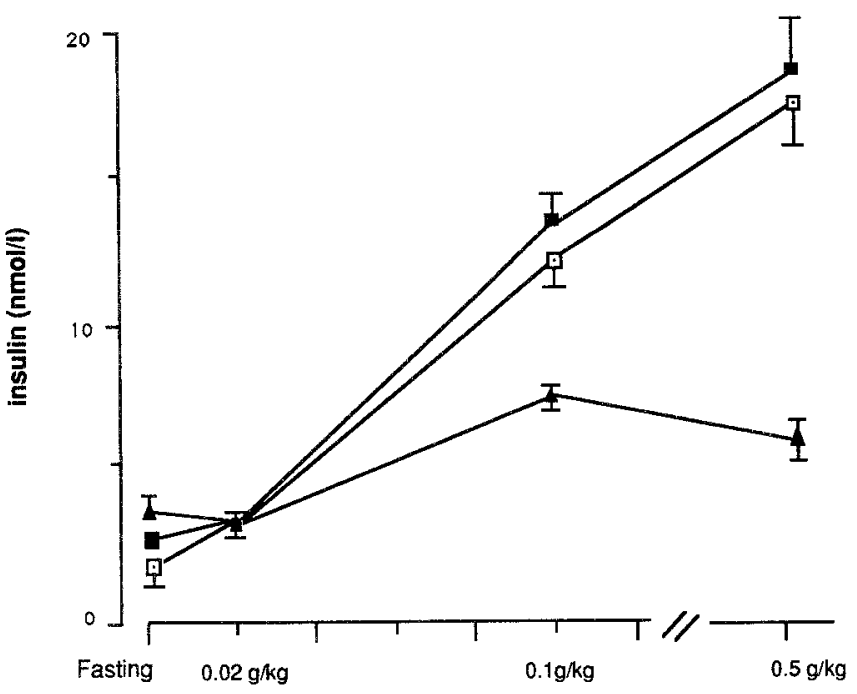

Fig. 1. Mean \pm SEM insulin levels when fasting and 3-10 min after thrce i.v. glucose loads $(0.02,0.1$ and $0.5 \mathrm{~g} / \mathrm{kg})$ in control subjects $(-\square-)$, pre-diabetic twins (- - ) and low risk non-diabetic twins (- - -)

age of the overall number of twins who had subnormal level; b) the sensitivity, by dividing the number of twins with subnormal levels who later developed diabetes by the overall number of twins who developed diabetes; and c) the specificity, by dividing the number of twins with normal levels who did not develop Type 1 diabetes by the total number of twins who did not develop diabetes.

\section{Statistical analysis}

Results are expressed as the mean $\pm \mathrm{SD}$. The significant variables approximated to a normal distribution in that $66 \%$ of the values fell within one SD of their mean. Changes were compared using a twotailed Student's $t$-test for paired or unpaired observations and Wilcoxon's rank sum test; changes were considered significant at $p<0.05$.

\section{Results}

\section{Fasting concentrations}

Fasting glucose levels in pre-diabetic twins were higher $(4.9 \pm 0.9 \mathrm{mmol} / \mathrm{l})$ than their control subjects $(4.2 \pm$ $0.3 \mathrm{mmol} / \mathrm{l}$ ) although the difference was not statistically significant $(p=0.09)$. Fasting insulin levels in the prediabetic twins $(4.2 \pm 2.0 \mathrm{nmol} / 1)$ were significantly higher than control levels $(1.8 \pm 1.8 \mathrm{nmol} / \mathrm{l} ; p<0.05)$. The low risk twins had similar blood glucose (Table 1) and insulin levels $(2.7 \pm 1.3 \mathrm{nmol} / \mathrm{l})$ compared to their control subjects $(2.1 \pm 1.7 \mathrm{nmol} / \mathrm{l})$ (Fig. 1). Within each group, glucose and insulin levels did not differ significantly before each i.v. glucose load at 0,120 and $180 \mathrm{~min}$.

\section{Responses to intravenous glucose}

Control subjects. Nine control subjects were studied; they had a mean $\mathrm{K}_{\mathrm{g}}$ of $1.8 \pm 0.6 \% / \mathrm{min}$ (range 1.1-2.9) (Table 1) and a mean FPIR to $0.5 \mathrm{~g} / \mathrm{kg}$ glucose of $137.5 \pm$ $44.6 \mathrm{nmol} \cdot 1^{-1} \cdot 10 \mathrm{~min}^{-1}$ (range 94-218).
As anticipated the total and mean 3-10 min insulin responses showed a step-wise increase with increasing glucose loads (Table 2, Fig. 1). Thus, the mean fasting insulin levels $(2.1 \pm 1.7 \mathrm{nmol} / \mathrm{l})$ were significantly lower than the mean of 3-10 min levels following $0.02 \mathrm{~g} / \mathrm{kg}$ glucose $(3.6 \pm 2.3 \mathrm{nmol} / 1 ; p<0.05)$ which were significantly lower than levels following $0.1 \mathrm{~g} / \mathrm{kg}$ glucose $(11.1 \pm 4.9 \mathrm{nmol} / \mathrm{l}$; $p<0.001$ ) which in turn were significantly lower than levels following $0.5 \mathrm{~g} / \mathrm{kg}$ glucose $(18.7 \pm 6.6 \mathrm{nmol} / 1$; $p<0.001$ ).

The dose-response relationship in all the control subjects approximated to a logarithmic curve with a high coefficient of determination (mean $R^{2} 0.92 \pm 0.07$; range $0.76-0.98$ ).

Values for $\mathrm{K}_{\mathrm{g}}$, FPIR and $\mathrm{R}^{2}$ below the normal range, that is below $1.1 \% / \mathrm{min}, 94 \mathrm{nmol} \cdot 1^{-1} \cdot 10 \mathrm{~min}^{-1}$ and 0.76 respectively, were considered subnormal.

Pre-diabetic twins. Of the seven pre-diabetic twins, one twin had her test terminated at 70 min due to inadequate venous access. This twin was excluded from calculation of insulin responses to 0.1 and $0.02 \mathrm{~g} / \mathrm{kg}$ glucose and calculation of $\mathrm{R}^{2}$.

Intravenous glucose clearance rates $\left(\mathrm{K}_{\mathrm{g}}\right)$ were significantly lower in the pre-diabetic twins when compared with control subjects $(1.0 \pm 0.5$ vs $1.9 \pm 0.7 \% / \mathrm{min}$; $p<0.05$ ) (Table 1 ).

The total insulin response to i.v. glucose was significantly lower in the pre-diabetic twins than the control subjects following glucose $0.5 \mathrm{~g} / \mathrm{kg}(p<0.00005)$ and $0.1 \mathrm{~g} / \mathrm{kg}$ $(p<0.05)$ but not following $0.02 \mathrm{~g} / \mathrm{kg}$ (Table 2). The FPIR to $0.5 \mathrm{~g} / \mathrm{kg}$ glucose injection was significantly lower in the pre-diabetic twins $\left(21.1 \pm 23.2 \mathrm{nmol} \cdot 1^{-1} \cdot 10 \mathrm{~min}^{-1}\right)$ than their control subjects $\left(143 \pm 50 \mathrm{nmol} \cdot 1^{-1} \cdot 10 \mathrm{~min}^{-1}\right.$; $p<0.0001)$ as was the calculated second phase insulin response $(29.2 \pm 23.2$ vs $219.5 \pm 86 \mathrm{nmol} / \mathrm{l} ; p<0.0001)$.

In contrast to control subjects, the pre-diabetic twins showed no step-wise increase in their responses to all three glucose loads; these responses did not differ significantly (Table 2, Fig. 1). The coefficient of determination $\left(\mathrm{R}^{2}\right)$ was significantly lower in the pre-diabetic twins $(0.41 \pm 0.39)$ than in the control subjects $(0.95 \pm 0.03$; $p<0.01$ ), reflecting loss of the normal glucose to insulin relationship.

Levels below the normal range were detected for $\mathrm{K}_{\mathrm{g}}$ in four of seven, FPIR in all seven, and for $\mathrm{R}^{2}$ in four of six of the pre-diabetic twins.

Low risk non-diabetic twins. Intravenous glucose clearance rates $\left(\mathrm{K}_{\mathrm{g}}\right)$ were similar in the low risk twins $(1.9 \pm 0.6 \% / \mathrm{min})$ and their control subjects $(1.8 \pm 0.7 \% /$ $\min )$.

The total insulin response in these twins was similar to control responses following i.v. glucose at $0.02 \mathrm{~g} / \mathrm{kg}$, $0.1 \mathrm{~g} / \mathrm{kg}$ and $0.5 \mathrm{~g} / \mathrm{kg}$ and increased in a step-wise manner following the different glucose loads (Table 2). The FPIR in the twins following glucose $0.5 \mathrm{~g} / \mathrm{kg}$ was similar to control responses $\left(149.2 \pm 93.2\right.$ vs $137.5 \pm 44.9 \mathrm{nmol} \cdot 1^{-1}$. $10 \mathrm{~min}^{-1}$ ) as was the calculated second phase insulin response $(226.1 \pm 157$ vs $224.7 \pm 92.9 \mathrm{nmol} / \mathrm{l})$. 
Table 2. Metabolic data on twins and control subjects

\begin{tabular}{|c|c|c|c|c|c|}
\hline & $\begin{array}{l}\text { Fasting } \\
\text { insulin } \\
\text { (nmol/l) }\end{array}$ & $\begin{array}{l}\text { Fasting } \\
\text { glucose } \\
(\mathrm{mmol} / \mathrm{l})\end{array}$ & $\begin{array}{l}\mathrm{K}_{\mathrm{g}} \\
(\% / \mathrm{min})\end{array}$ & $\mathrm{R}^{2}$ & $\begin{array}{l}\text { FPIR } \\
\left(\mathrm{nmol} \cdot 1^{-1}\right. \\
\left.10 \mathrm{~min}^{-1}\right)\end{array}$ \\
\hline \multicolumn{6}{|c|}{ Control subjects } \\
\hline 1 & 0.3 & 4.0 & 1.8 & 0.96 & 113 \\
\hline 2 & 1.2 & 4.0 & 2.7 & 0.96 & 94 \\
\hline 3 & 1.0 & 4.1 & 1.3 & 0.90 & 116 \\
\hline 4 & 1.7 & 3.9 & 2.9 & 0.94 & 147 \\
\hline 5 & 3.7 & 3.9 & 2.2 & 0.76 & 126 \\
\hline 6 & 0.7 & 4.5 & 1.9 & 0.95 & 105 \\
\hline 7 & 2.0 & 4.3 & 1.1 & 0.98 & 205 \\
\hline 8 & 2.3 & 3.6 & 1.2 & 0.89 & 114 \\
\hline 9 & 5.9 & 4.8 & 1.4 & 0.93 & 218 \\
\hline \multicolumn{6}{|c|}{ Pre-diabetic twins } \\
\hline 1 & 1.3 & 4.0 & 0.5 & 0.44 & 29 \\
\hline 2 & 3.5 & 6.4 & 0.7 & 0.15 & 0 \\
\hline 3 & 5.3 & 4.8 & 0.6 & - & 4 \\
\hline 4 & 6.7 & 3.7 & 1.8 & 0.95 & 25 \\
\hline 5 & 6.1 & 4.6 & 0.9 & 0.81 & 65 \\
\hline 6 & 4.2 & 5.0 & 1.2 & 0.10 & 26 \\
\hline 7 & 1.2 & 5.7 & 1.2 & 0.02 & 0 \\
\hline \multicolumn{6}{|c|}{ Low risk twins } \\
\hline 8 & 0.1 & 3.8 & 2.1 & 0.99 & 218 \\
\hline 9 & 3.7 & 3.8 & 1.6 & 0.97 & 109 \\
\hline 10 & 3.5 & 4.5 & 1.0 & 0.97 & 84 \\
\hline 11 & 1.3 & 4.0 & 2.2 & 0.99 & 35 \\
\hline 12 & 3.5 & 4.7 & 1.5 & 0.21 & 89 \\
\hline 13 & 2.3 & 4.0 & 2.3 & 0.99 & 198 \\
\hline 14 & 2.8 & 4.2 & 2.2 & 0.89 & 195 \\
\hline 15 & 2.8 & 4.1 & 2.3 & 0.99 & 325 \\
\hline 16 & 0.4 & 3.8 & 2.6 & 0.94 & 115 \\
\hline 17 & 3.6 & 4.0 & 2.3 & 0.99 & 175 \\
\hline 18 & 3.6 & 4.1 & 1.3 & 0.13 & 21 \\
\hline 19 & 4.7 & 4.5 & 1.4 & 0.93 & 133 \\
\hline 20 & 3.8 & 4.5 & 1.0 & 0.98 & 41 \\
\hline 21 & 2.8 & 4.2 & 2.8 & 0.99 & 186 \\
\hline 22 & 1.5 & 2.5 & 1.4 & 0.99 & 312 \\
\hline
\end{tabular}

FPIR, first phase insulin response; $\mathrm{R}^{2}$, coefficient of determination; $\mathrm{K}_{\mathrm{g}}$, rate of glucose clearance

The mean 3-10 min insulin responses to each glucose load increased in a step-wise fashion so that the fasting insulin levels $(2.7 \pm 1.3 \mathrm{nmol} / \mathrm{l})$ were significantly lower than the levels following $0.02 \mathrm{~g} / \mathrm{kg}$ glucose $(3.8 \pm 1.5 \mathrm{nmol} / \mathrm{l}$; $p<0.01$ ), which were lower than the levels following $0.1 \mathrm{~g} / \mathrm{kg}(11.6 \pm 5.7 \mathrm{nmol} / \mathrm{l} ; p<0.0001)$, which in turn was lower than the levels following $0.5 \mathrm{~g} / \mathrm{kg}(20.4 \pm 11.0$ $\mathrm{nmol} / \mathrm{l} ; p<0.01$ ) (Fig. 1).

Table 3. Total insulin responses $\left(\mathrm{nmol} \cdot \mathrm{l}^{-1} \cdot 30 \mathrm{~min}^{-1}\right)$ to three i.v. glucose loads in pre-diabetic and low risk twins, with their respective control subjects shown in parenthesis

\begin{tabular}{lccc}
\hline & \multicolumn{3}{l}{ Total insulin response } \\
\cline { 2 - 4 } & $0.02 \mathrm{~g} / \mathrm{kg}$ & $0.1 \mathrm{~g} / \mathrm{kg}$ & $0.5 \mathrm{~g} / \mathrm{kg}$ \\
\hline Pre-diabetic & $15 \pm 25$ & $43 \pm 39$ & $56 \pm 47$ \\
twins & $(24 \pm 23)$ & $(114 \pm 63)$ & $(362 \pm 118)$ \\
Low risk & $23 \pm 24$ & $117 \pm 71$ & $375 \pm 237$ \\
non-diabetic & $(20 \pm 21)$ & $(107 \pm 57)$ & $(362 \pm 117)$ \\
twins & & & \\
\hline
\end{tabular}

Results given as mean $\pm \mathrm{SD}$
The coefficient of determination $\left(\mathrm{R}^{2}\right)$ in the twins $(0.86 \pm 0.28)$ and control subjects $(0.92 \pm 0.07)$ was similar. Only two of the low risk twins showed low $\mathrm{R}^{2}$ value of 0.13 (patient 18) and 0.21 (patient 12, Table 1). Patient 18 is now 7.6 years discordant from the diagnosis of diabetes in his index twin. At the time of testing, he was ICA negative with normal oral glucose tolerance and $\mathrm{K}_{\mathrm{g}}(1.3 \% / \mathrm{min})$ but a subnormal FPIR $\left(21.1 \mathrm{nmol} \cdot \mathrm{I}^{-1} \cdot 10 \mathrm{~min}^{-1}\right)$. He remains ICA negative with normal oral glucose tolerance and a $\mathrm{K}_{\mathrm{g}}$ of $0.8 \% / \mathrm{min}$. Patient 12 is now 21.1 years from the diagnosis of her index twin. At the time of testing, she was ICA negative with normal glucose tolerance and $\mathrm{K}_{\mathrm{g}}$ $(1.5 \% / \mathrm{min})$ but subnormal FPIR $\left(89.6 \mathrm{nmol} \cdot 1^{-1} \cdot 10\right.$ $\left.\min ^{-1}\right)$. She now has impaired glucose tolerance but remains ICA negative.

Of the low risk twins, levels below the normal range were detected for $\mathrm{K}_{\mathrm{g}}$ in two of the 15 twins; for FPIR in five of 15 and for $R^{2}$ in two of 15 .

\section{Islet cell antibodies}

All seven pre-diabetic twins but none of the low risk twins had ICA at the time of the study.

\section{Predictive values}

The cohort of 22 non-diabetic twins were followed-up prospectively until they developed Type 1 diabetes or were, by actuarial analysis, unlikely to do so. In this cohort a subnormal $\mathrm{K}_{\mathrm{g}}$ (less than $1.1 \% / \mathrm{min}$ ) as a predictor of Type 1 diabetes had a positive predictive value of $67 \%$, a specificity of $87 \%$ and a sensitivity of $57 \%$. A subnormal FPIR (less than $94 \mathrm{nmol} \cdot \mathrm{l}^{-1} \cdot 10 \mathrm{~min}^{-1}$ to $0.5 \mathrm{~g} / \mathrm{kg}$ glucose) had a positive predictive value of $58 \%$, a specificity of $67 \%$ and a sensitivity of $100 \%$. One patient was excluded from the pre-diabetic twin group for calculation of $\mathbf{R}^{2}$ as her test was incomplete. A subnormal $\mathrm{R}^{2}$ (less than 0.76) in the remaining cohort of 21 non-diabetic twins had a positive predictive value for Type 1 diabetes of $67 \%$, a specificity of $87 \%$ and a sensitivity of $67 \%$.

\section{Discussion}

These observations demonstrate that twins tested at a mean of 7 months before they developed Type 1 diabetes had a decreased maximum insulin secretory response to i.v. glucose and a loss of the normal glucose to insulin dose-response relationship. In contrast, the group of twins who remain non-diabetic and are now unlikely to develop Type 1 diabetes had similar insulin responses and similar glucose to insulin dose-response relationship to the control subjects.

The degree of insulin response in normal subjects increases progressively with increasing glucose loads. The FPIR reaches a maximum at a $10-20 \mathrm{~g}$ glucose load [7]. For this present study we selected glucose loads from the studies of Porte and his colleagues to define the normal glucose to insulin dose-response relationship [7]. To exclude the potential effect of hyperglycaemia in augment- 
ing the glucose-induced insulin response we allowed the blood glucose to return to normal after each glucose challenge. It has been established that these different glucose loads and their sequence of administration do not potentiate insulin release [7]. In our study the glucose loads were given in descending order. Insulin responses were calculated as areas under the curve, a method which limits errors in reproducibility [10].

Our control subjects showed a step-wise increase in first phase, second phase and total insulin responses with increasing glucose loads. In addition, the mean 3-10 min insulin responses also increased in a step-wise manner and provided the anticipated dose-response relationship with a high degree of "fit" in a non-linear logarithmic curve fitting programme. In contrast, the pre-diabetic twins did not demonstrate such a step-wise increase in these insulin responses. There was no further increase in their total insulin response to glucose loads above $0.02 \mathrm{~g} / \mathrm{kg}$ suggesting that their maximum response had been attained [11, 12]. These pre-diabetic twins also had a lower total insulin response than their control counterparts at both 0.5 and $0.1 \mathrm{~g} / \mathrm{kg}$ glucose loads. Their mean maximum insulin secretory response to glucose was reduced to $16 \%$ (calculated at $0.5 \mathrm{~g} / \mathrm{kg}$ ) of the control response at a mean of 7 months before the onset of clinical diabetes.

Loss of the normal glucose to insulin relationship in these pre-diabetic twins is consistent with a qualitative defect in Beta-cell function before the onset of Type 1 diabetes. Two other qualitative abnormalities of Beta-cell function in this pre-diabetic period have been described, namely, a differential sensitivity to glucose and non-glucose stimuli, and an increased proportion of secreted fasting proinsulin to insulin [13-15]. We cannot assess from this study whether the loss of both the normal dose-response relationship and their maximum Beta-cell secretory response to glucose occurs simultaneously or separately. However, two pre-diabetic twins had normal glucose to insulin response curves when their FPIR was subnormal.

These changes in Beta-cell function might have predictive value. A decreased FPIR gave a positive predictive value of $58 \%$ in this study and $88 \%$ in the only other study reported [16]. That study differed from ours in several important respects; it was a study of siblings and not twins, selected because they had ICA and were followed-up for an insufficient period to be certain that the remaining nondiabetic siblings had a low risk for disease. Finally, the positive predictive value of a decreased $\mathrm{R}^{2}$ in our study was $67 \%$, comparable to that for a subnormal FPIR. To determine whether a decreased $R^{2}$ could supplement other established metabolic tests as a predictor of diabetes will require further investigation.

The low risk non-diabetic twins had similar insulin responses to their control subjects at each glucose challenge. Previous reports of insulin responses in twins and siblings who are genetically susceptible to Type 1 diabetes but at low disease risk have been contradictory. In two studies, such individuals had an increased insulin response to i.v. glucose but these tests were immediately preceded either by oral glucose or i.v. arginine $[17,18]$. More recently, siblings of diabetic patients tested for their insulin response to $i . v$. arginine and their insulin sensitivity, using a minimal-modelling technique, had a decrease in both insulin sensitivity and Beta-cell function [19]. Our results on 15 low risk twins, as a group, failed to demonstrate impaired Beta-cell function; however, five of them had subnormal insulin responses and two of these five also had an abnormal glucose to insulin response relationship. This observation is consistent with our hypothesis that immune and metabolic changes can occur in individuals genetically susceptible to Type 1 diabetes and yet do not lead on to diabetes [20-22].

The metabolic changes which can precede Type 1 diabetes include impaired glucose tolerance [20], hyperproinsulinaemia [13], a differential response to glucose and glucagon $[14,15]$, loss of the normal glucose to insulin response relationship and a decreased insulin response to i. v. glucose [23], which we have now shown is due to a loss of the maximum insulin secretory response to glucose.

Acknowledgements. This study was supported by the Wellcome Trust, Juvenile Diabetes Foundation, Medical Research Council and Diabetic Twin Research Trust. We thank Ms. M. Shattock and Prof. G.F.Bottazzo for testing for islet cell antibodies and Ms. A.Corcoran for technical help.

\section{References}

1. Leslie RDG, Lazarus N, Vergani D (1989) Events leading to insulin-dependent diabetes. Clin Sci 76: 119-124

2. Foulis AK, Farquharson MA, Meager A (1987) Immunoreactive alpha-interferon in insulin-secreting beta cells on Type 1 diabetes mellitus. Lancet II: 1423-1427

3. Srikanta S, Garda OP, Gleason RE, Jackson RA, Soeldner JS, Eisenbarth GS (1984) Pre Type 1 diabetes linear loss of beta cell response to intravenous glucose. Diabetes 33: 717-720

4. National Diabetes Data Group (1979) Classification and diagnosis of diabetes mellitus and other categories of glucose intolerance. Diabetes 28: 1039-1057

5. Barnett AH, Eff C, Leslie RDG, Pyke DA (1981) Diabetes in identical twins. Diabetologia 20: 87-93

6. Olmos P, A'Hern R, Heaton DA et al. (1988) The significance of the concordance rate for Type 1 (insulin-dependent) diabetes in identical twins. Diabetologia 31: 747-750

7. Lerner RL, Porte D (1971) Relationships between intravenous glucose loads, insulin responses and glucose disappearance rate. J Clin Endocrinol 33: 409-417

8. Morgan CR, Lazarow A (1963) Immunoassay of insulin: two antibody system. Plasma insulin levels of normal, subdiabetic and diabetic rats. Diabetes 12: 115-126

9. Tarn AC, Thomas JM, Dean BM et al. (1988) Predicting insulindependent diabetes. Lancet I: $845-850$

10. Smith CP, Tarn AC, Thomas JM et al. (1988) Between and within subject variation to the first phase insulin response to intravenous glucose. Diabetologia 31: 123-125

11. Weir GC, Bonner-Weir S, Leahy JL (1990) Islet mass and function in diabetes and transplantation. Diabetes 39: 401-405

12. Ward WK, Bolgiano DC, McKnight B, Halter JB, Porte D (1984) Diminished B-cell secretory capacity in patients with non-insulin dependent diabetes mellitus. J Clin Invest 74: 1318-1328

13. Heaton D, Millward BA, Gray IP et al. (1988) Increased proinsulin levels as an early indicator of beta cell dysfunction in nondiabetic twins of Type 1 (insulin-dependent) diabetic patients. Diabetologia 31: 182-184

14. Heaton DA, Lazarus NR, Pyke DA, Leslie RDG (1989) B-cell responses to intravenous glucose and glucagon in non-diabetic twins of patients with Type 1 (insulin-dependent) diabetes mellitus. Diabetologia 32: 814-817 
15. Bardet S, Rohmer V, Maugendre D et al. (1991) Acute insulin response to intravenous glucose, glucagon and arginine in some subjects at risk for Type 1 (insulin-dependent) diabetes mellitus. Diabetologia 34: 648-654

16. Vardi P, Crisa L, Jackson RA et al. (1991) Predictive value of intravenous glucose tolerance test insulin secretion less than or greater than the first percentile in islet cell antibody positive relatives of Type 1 (insulin-dependent) diabetic patients. Diabetologia 34: 93-102

17. Heaton DA, Millward BA, Gray P et al. (1987) Evidence of Bcell dysfunction which does not lead on to diabetes: a study of identical twins of insulin dependent diabetics. Br Med J 294: 145-146

18. Hollander CH, Asplin CM, Kniaz D, Hansen JA, Palmer JP (1982) Beta-cell dysfunction in nondiabetic HLA identical siblings of insulin-dependent diabetes. Diabetes 31:149-153

19. McCulloch DK, Klaff LJ, Kahn SE et al. (1990) Nonprogression of subclinical B-cell dysfunction among first-degree relatives of IDDM patients. Diabetes 39: 549-556

20. Millward BA, Alviggi L, Hoskins PJ et al. (1986) Immune changes associated with insulin dependent diabetes may remit without causing the disease: a study in identical twins. Br Med J 292: 793-796
21. Beer SF, Heaton DA, Alberti KGMM, Pyke DA, Leslie RDG (1990) Impaired glucose tolerance precedes but does not predict insulin-dependent diabetes mellitus: a study of identical twins. Diabetologia 33: 497-502

22. Leslie RDG, Pyke DA (1991) Escaping insulin-dependent diabetes. Br Med J 302: 1103-1104

23. Srikanta S, Ganda OP, Gleason RE, Jackson RA, Soeldner JS, Eisenbarth GS (1984) Pre-Type 1 diabetes: linear loss of beta cell response to intravenous glucose. Diabetes 33: 717-720

Received: 5 August 1991

and in revised form: 18 November 1991

Dr.R.D.G.Leslie

Diabetes Research Unit

Charing Cross and Westminster Medical School

17, Horseferry Road

London SW1P 2AR

UK 